Клімова А. В., аспірант, завідувач відділу ліцензування та акредитації (Національний університет водного господарства та природокористування, м. Рівне)

\title{
ФУНКЦІї ЛІЦЕНЗУВАННЯ ЯК ІНСТРУМЕНТУ ДЕРЖАВНОГО РЕГУЛЮВАННЯ У СФЕРІ ВИЩОЇ ОСВІТИ УКРАЇНИ
}

Стаття присвячена розгляду сутності поняття «ліцензування», що $€$ одним із засобів регулюючого впливу з боку держави на діяльність суб'єктів господарювання щодо початку, провадження окремо визначених видів діяльності та подальшого контролю за її здійсненням 3 метою забезпечення захисту прав, законних інтересів громадян, держави і суспільства.

Автором висвітлена роль держави як гаранта забезпечення прав $\mathbf{i}$ задоволення потреб у сфері освіти, забезпечення відповідності освітньої діяльності запитам суспільства в умовах глобалізації та інтернаціоналізації вищої освіти, посиленні конкуренції та розвитку автономії закладів вищої освіти. При цьому доведено, що державне регулювання $є$ переважаючою формою впливу на розвиток вищої освіти в Україні, оскільки держава виступаючи одним з суб'єктів макроекономіки, головною функцією якого є організація виробництва суспільних благ, забезпечує регулювання економіки, визначає умови і правила ведення господарської діяльності, встановлює певні вимоги і обмеження діяльності суб'єктів господарювання, включаючи їх відповідальність за правопорушення у сфері господарювання. Тоді як ліцензування є одним із інструментів регулюючого впливу держави на заклади вищої освіти та відноситься до адміністративних методів, коли необхідний результат досягається за допомогою прямого впливу центрального органу державної влади в сфері освіти на заклади освіти.

Досліджено роль ліцензування освітньої діяльності як елемента системи зовнішнього забезпечення якості вищої освіти. Автором визначенні функції ліцензування, зокрема: регулятивна, легітимаційна, контролююча, фіскальна, дозвільна, інформаційна, облікова, статистична, охоронна, та розкритий зміст кожної функції.

Ключові слова: вища освіта, державне регулювання надання освітніх послуг, зовнішнє забезпечення якості вищої освіти, ліцензування освітньої діяльності. 
Посилення глобалізації та інтернаціоналізації справляє трансформуючий вплив на економічні умови діяльності закладів вищої освіти. Виклики розвитку транскордонної освіти посилюють конкуренцію між закладами освіти за залучення іноземних студентів. В наслідок чого змінюються підходи до управління освітніми системами на рівні держав та організаційні стратегії внутрішнього управління закладами вищої освіти [1]. Освіта є суспільним явищем, яке орієнтоване на побудову громадянського суспільства та впливає на всі сфери економіки. Входження України в освітній простір Європи, реформування вищої освіти в умовах глобалізаційних процесів, з одного боку, та розвиток автономії закладів вищої освіти, розширення академічної мобільності здобувачів вищої освіти, з іншого боку, потребують побудови якісної системи вищої освіти, що впливає на темпи економічного зростання та добробуту населення.

Аналіз останніх досліджень і публікацій. Питання державного регулювання сфери вищої освіти $€$ інтересом як освітян, так і економістів, правників, політологів, соціологів, державних службовців і політиків. Питання державного регулювання вищої освіти в Україні досліджували в своїх наукових роботах В. Кремінь, П. Курмаєв, О. Калініна, В. Луговий, О. Поступна, А. Тамм, Т. Фініков. Фундаментальну основу дослідження ліцензування господарської діяльності становлять праці науковців-юристів, це, зокрема, Деревянко Б., Карчевський К., Жилінський С., Кашперський О., Олейник О., Авер'янова $Є$. Різні аспекти ліцензування освітньої діяльності закладами вищої освіти розглядаються в наукових працях А. Баженової, В. Бахрушина В. Лугового, М. Савченка, Т. Червякової, Т. Фінікова.

Постановка завдання. Метою дослідження $\epsilon$ визначення теоретичних основ ліцензування господарської діяльності як інструменту державного регулювання, та місця ліцензування освітньої діяльності закладами вищої освіти як одного з елементів системи зовнішнього забезпечення якості.

Викладення основного матеріалу. Держава $є$ одним з суб'єктів макроекономіки, головною функцією якого $є$ організація виробництва суспільних благ. У такій якості вона забезпечує регулювання економіки, визначає умови і правила ведення господарської діяльності, встановлює певні вимоги і обмеження діяльності суб'єктів господарювання, включаючи їх відповідальність за правопорушення у сфері господарювання. Господарським кодексом України визначається, що «держава для реалізації економічної політики, виконання цільових економічних та інших програм і програм економічного і соціального розвитку застосовує різноманітні засоби і механізми регулювання господарської діяльності». При чому законодавчо закріпляється, що 
основними засобами регулюючого впливу держави на діяльність суб'єктів господарювання є: державне замовлення; ліцензування, патентування і квотування; технічне регулювання; застосування нормативів та лімітів; регулювання цін і тарифів; надання інвестиційних, податкових та інших пільг; надання дотацій, компенсацій, цільових інновацій та субсидій [3].

Задекларовані засоби державного регулювання є інструментами економічної політики держави, які застосовуються в залежності від можливостей суб'єкта господарювання вступати до тих чи інших економічних відносин.

На сьогоднішній день в умовах жорсткої конкуренції серед закладів вищої освіти надважливого значення набуло питання забезпечення якості вищої освіти. Для надання якісних послуг в сфері вищої освіти необхідно мати достатній матеріально-технічний, інформаційний та кадровий та науковий потенціал. Тоді як наявність великої кількості малопотужних за освітнім та науковим потенціалом закладів вищої освіти негативно впливає на розвиток якості вищої освіти. Розвиток державної та недержавної вищої освіти вимагає їі державного регулювання, удосконалення практичних форм та методів підвищення якості освіти та розвитку науково-теоретичних основ підвищення ефективності управління вищою освітою.

Вєльчева B.І. в своїх дослідженнях зазначає, що категорія освіти має складний, міждисциплінарний, багатоаспектний характер, що одержує в різних галузях науки свій специфічний зміст як соціальної системи, однієї з підсистем суспільства, як соціального явища, соціального інституту, системи соціальних зв'язків, психологопедагогічного феномену, освітньої послуги як економічної категорії та ін. Тобто саме поняття “освіта” розглядається в науці та практичній діяльності, одночасно, як соціальна цінність, як система, як процес і як результат, що ускладнює формалізацію його як об'єкта управління. I саме держава повинна стати гарантом забезпечення прав і задоволення потреб у сфері освіти, взяти на себе функцію забезпечення відповідності освітньої діяльності запитам особи і суспільства. Дослідниця в своїй роботі підкреслює, що саме держава повинна стати гарантом забезпечення прав і задоволення потреб у сфері освіти, взяти на себе функцію забезпечення відповідності освітньої діяльності запитам особи і суспільства, і що державне регулювання визнається переважаючою формою впливу на розвиток вищої освіти з боку держави [4].

В своїх роботах Кобець А.С. зазначає, що «формуючи основи державного регуляторного механізму, треба виходити з того, що ри- 
нок - це потреби сьогоднішнього дня, а освіта закладає основу довгострокового розвитку країни. Основна проблема полягає у встановленні раціональних меж державного регулювання в умовах зростаючої автономії закладів вищої освіти, вдосконаленні діючих і виробленні нових механізмів державного регулювання вищої школи, адекватних сучасним тенденціям розвитку освітнього ринку» та класифікує методи державного регулювання освітньої сфери в залежності від засобів впливу на правові, економічні, адміністративні, донорські та морально-етичні [5]. Ряд дослідників В.В. Шпаков [6], А.С. Кобець [5], П.В. Михайлушкин [7], О.М. Кудрейко [8] зазначають, що держава здійснює свій регулюючий вплив на суб'єкти господарювання i, зокрема, в галузі вищої освіти в основному за допомогою економічних та адміністративних методів. При використанні економічних методів, коли держава досягає результату через економічний інтерес виконавців, що полягає в створенні економічного середовища, яке зумовлює поведінку суб'єктів господарювання на ринку з врахуванням державних пріоритетів. До таких методів можна віднести: державне кредитування суб'єктів господарювання, державне замовлення, встановлення податкових пільг, надання дотацій, амортизаційні відрахування тощо. При використанні адміністративних методів необхідний результат досягається, за допомогою прямого впливу центральних органів державної влади (державна реєстрація суб'єктів господарювання, ліцензування певних видів господарської діяльності, акредитація, встановлення стандартів освітньої діяльності та стандартів вищої освіти). Адміністративні методи регулювання $є$ діаметрально протилежними до розвитку саморегулюючого ринку, вони блокують дії відповідних ринкових регуляторів, але в умовах переходу до ринкової економіки вони мають важливе значення та використовуються для захисту прав споживачів.

Враховуючи вищевикладене та дослідження науковців в галузі державного регулювання господарської діяльності і освітньої сфери, можна зробити висновок, що одним із методів регулюючого впливу держави на заклади вищої освіти є ліцензування освітньої діяльносTi.

3 метою розгляду ліцензування як методу регуляторного впливу держави, необхідно з'ясувати сутність поняття «ліцензування», «ліцензія». Під час здійснення господарської діяльності суб'єктами господарювання, державного регулювання такої діяльності, в законодавстві та правничих науках поняття «ліцензування» зустрічається достатньо часто. Разом з тим це поняття не $є$ однозначним, знаходиться в постійній трансформації та трактується науковцями з використанням різних підходів. Розглядаючи правову основу ліцензуван- 
ня Карчевський К.А. стверджує, що «ліцензування - це правовідносини, пов'язані з наданням суб'єктам господарювання, які відповідають встановленим вимогам (ліцензійним умовам), тимчасового дозволу на заняття певним видом (видами) господарської діяльності, який встановлений законодавством, що здійснюється спеціально уповноваженими державними органами шляхом вчинення ліцензійних дій, встановлених законодавством» [9]. Шестак Л.В. зазначає, що «ліцензування - це порядок надання дозволів на здійснення окремих видів діяльності спеціально уповноваженими на те державою органами» вважаючи, що «ліцензування є однією з форм державної виконавчої діяльності, яка виражена у вигляді офіційного визнання державою за визначеними суб'єктами прав на провадження окремих, передбачених законодавством України, видів господарської діяльності, які вимагають достатнього рівня професіоналізму і кваліфікації, а також здійснення контролю за фактично здійснюваними діями в інтересах особи, держави і суспільства» [10]. А. Шпомер розглядає ліцензування як сукупність засобів, установлених державною, пов'язаних із видачею ліцензій, переоформлення та анулювання їх, із наглядом органів, що видають ліцензії, за дотриманням суб'єктами господарювання відповідних ліцензійних умов [11]. Авер'яновою $Є$. дається наступне визначення ліцензування господарської діяльності - «це засіб державного регулювання господарської діяльності, виражений у комплексі дій уповноважених органів державної влади щодо офіційного визнання відповідності суб'єкта господарювання умовам та характеристикам, необхідним для здійснення певного виду господарської діяльності, та подальшого контролю за дотриманням ліцензійних умов» [12]. Олейник 0. [2] та Пастух І. [13] в своїх дослідженнях визначають ліцензування як правовий режим провадження окремих встановлених законодавством видів господарської діяльності, що передбачає державне підтвердження та визначення меж прав на їх здійснення, контроль за цією діяльністю та можливість її припинення за особливими підставами з боку повноважних органів держави.

Аналізуючи наукові праці можна зробити висновок, що розуміння ліцензування, як діяльності, а ліцензії, як документа, не є повним. Оскільки дана діяльність не обмежується лише діяльністю державних органів, а передбачає подачу заяви про надання ліцензії суб'єктами господарювання до відповідних органів ліцензування, а також цілу систему правовідносин, які пов'язані з видачею, анулюванням ліцензії, веденням ліцензійних справ та ліцензійних реєстрів, контролем за дотриманням ліцензійних умов ліцензіатами, 
видачею розпоряджень про усунення порушень ліцензійних умов та законодавства в сфері ліцензування, то науковцями ліцензування розглядається через призму правовідносин.

Законодавче закріплення понять «ліцензія» та «ліцензування» здійснене, по-перше, в Законі України «Про ліцензування видів господарської діяльності» [14], де ліцензування визначається як засіб державного регулювання провадження видів господарської діяльності, що підлягають ліцензуванню, спрямований на забезпечення реалізації єдиної державної політики у сфері ліцензування, захист економічних і соціальних інтересів держави, суспільства та окремих споживачів, а ліцензія - це запис у Єдиному державному реєстрі юридичних осіб, фізичних осіб-підприємців та громадських формувань про рішення органу ліцензування щодо наявності у суб'єкта господарювання права на провадження визначеного ним виду господарської діяльності, що підлягає ліцензуванню; по-друге, у п. 1 ст. 14 Господарського кодексу ліцензування поряд з патентуванням певних видів господарської діяльності та квотування є засобами державного регулювання у сфері господарювання, спрямованими на забезпечення єдиної державної політики у цій сфері та захист економічних і соціальних інтересів держави, суспільства та окремих споживачів [3]. Як бачимо визначення поняття ліцензування, закріплені в Законі України «Про ліцензування видів господарської діяльності» та Господарському кодексі, є ідентичними і визначає ліцензування як засіб державного регулювання.

Закон України «Про вищу освіту» містить визначення ліцензування, як процедури визнання спроможності юридичної особи провадити освітню діяльність за певною спеціальністю на певному рівні вищої освіти відповідно до стандартів освітньої діяльності [15]. Ліцензування освітньої діяльності відповідно до Закону України «Про освіту» - «це процедура визнання спроможності юридичної або фізичної особи надавати освітні послуги на певному рівні освіти відповідно до ліцензійних умов» [16]. В зазначених законах поняття «ліцензування» базується на підходах до даного визначення в Цивільному кодексі України. Фактично ліцензування розглядається як елемент легітимації суб'єкта господарювання, що є умовою набуття ним цивільної правоздатності, коли юридична особа може здійснювати окремі види діяльності, перелік яких встановлюється законом, тільки після одержання нею спеціального дозволу - ліцензії.

Аналіз чинного законодавства у сфері ліцензування [14] та досліджень, проведених Червяковою Т. [17] та Шпомер А. [18], дозволяє виділити наступні функції ліцензування господарської діяльності і, зокрема, освітньої діяльності, та розкрити їх зміст: 
1) Регулятивна функція - держава здійснюючи ліцензування встановлює певні варіанти поведінки надаючи суб'єкту господарювання позитивні суб'єктні права і покладаючи на нього юридичні обов'язки і тим самим впорядковує суспільні відносини.

2) Легітимаційна функція, яка полягає в тому, що наявність ліцензії підтверджує законність та легітимність права суб'єкта господарювання на здійснення вказаної в даному документі діяльності.

3) Контролююча функція, яка має подвійний зміст. По-перше, прийняттю рішення про надання ліцензії передує перевірка (експертиза) відповідності суб'єкта господарювання встановленим вимогам і умовам. Тобто за допомогою ліцензування здійснюється контроль за допуском претендентів в ті сфери, де для забезпечення балансу публічних і приватних інтересів необхідне дотримання певних параметрів (рівень кваліфікації, матеріальна база тощо). По-друге, орган ліцензування здійснює контроль за додержанням суб'єктами господарювання, що отримали ліцензію, вимог ліцензійних умов та за результатами перевірки приймає відповідні рішення, а спеціально уповноважений орган з питань ліцензування здійснює нагляд за додержанням органами державної влади, державними колегіальними органами законодавства у сфері ліцензування.

4) Фіскальна функція, коли плата, що стягується за видачу ліцензій, є одним з джерел державних доходів.

5) Дозвільна функція - держава в особі органів ліцензування дає дозвіл на провадження певного виду діяльності, чим засвідчує, що суб'єкт господарювання має необхідну матеріальну базу, належний кваліфікаційний рівень працівників, відповідає технологічним вимогам, тобто відповідає всім організаційним і економічним вимогам законодавства щодо здійснення певного виду діяльності.

6) Інформаційна функція - орган ліцензування розміщує на своєму офіційному веб-сайті інформацію про прийняті ним рішення за відповідним видом господарської діяльності, надає інформацію з ліцензійних справ та у паперовій формі відповідно до порядку встановленому Законом України «Про доступ до публічної інформації» та здійснює інформаційне та методичне супроводження ліцензування.

7) Облікова функція - орган ліцензування формує та веде ліцензійні справи, вносить до Єдиного державного реєстру юридичних осіб, фізичних осіб - підприємців та громадських формувань прийняті ним рішення, документи та інші відомості про ліцензування видів господарської діяльності.

8) Статистична функція - орган ліцензування складає та подає спеціально уповноваженому органу з питань ліцензування щорічний 
ліцензійний звіт. В свою чергу Спеціально уповноважений орган 3 питань ліцензування одержує інформацію з питань ліцензування та контролю за наявністю ліцензій у суб'єктів господарювання від органів ліцензування, органів, що здійснюють контроль за наявністю ліцензій, зокрема щорічний ліцензійний звіт та щорічний звіт про виявлення безліцензійної діяльності. За цими даними можна досліджувати ринкове середовище господарської діяльності та здійснювати прогнозування розвитку підприємництва у сфері, що підлягає ліцензуванню

9) Охоронна функція - ліцензування $є$ засобом охорони інтересів учасників суспільних відносин від наслідків потенційно небезпечного господарювання.

Авторами моніторингового дослідження на тему «Моніторинг інтеграції української системи вищої освіти в Європейський простір вищої освіти та наукового дослідження» [19] відзначається, що лише з прийняттям у 2014 році Закону України «Про вищу освіту» в системі ліцензування освітньої діяльності поряд з акредитацією, відбувається ії трансформація в базову технологію стимулювання якості вищої освіти. При цьому основними принципами трансформації мають стати: 1) система повинна бути простою, логічною, зрозумілою та прозорою; 2) нормативи та вимоги мають бути адекватними, об'єктивними, вимірними та піддаватися верифікації; 3) базові показники мають бути зорієнтовані на позитивну оцінку динамічності розвитку навчального закладу як ознаки його конкурентоспроможності та адаптивності; 4) система ліцензування та акредитації (показники, процедури та процеси) має стимулювати, а не гальмувати розвиток вітчизняної вищої школи; 5) ліцензійно-акредитаційний менеджмент в Україні повинен бути спрямований на прискорену інтеграцію національної освітньої системи в Європейський простір вищої освіти та наукових досліджень; 6) подальший розвиток системи ліцензування та акредитації неможливий без розширення ролі та участі професійної спільноти і громадського контролю за нею; 7) система ліцензування та акредитації має бути спрямована на внутрішнє та зовнішнє забезпечення якості вищої освіти; 8) ліцензійно-акредитаційна система повинна стати одним з головних чинників переходу від фрагментарної координації до ефективної кооперації вищої школи, ринку праці, самоврядних професійних спільнот, інших інститутів громадянського суспільства.

Висновки. Вивчивши роботи науковців та нормативно-правову базу можна зробити наступні висновки:

1. Ліцензування господарської діяльності в Україні і освітньої діяльності, зокрема, спрямоване не на обмеження свободи госпо- 
дарської діяльності, а на перевірку відповідності закладів освіти визначеним у законодавстві вимогам та ліцензійним умовам провадження освітньої діяльності.

2. Ліцензування освітньої діяльності у сфері вищої освіти можна розглядати як окрему частину державного регулювання освітніх послуг, що стане предметом подальшого дослідження.

3. Ліцензування є дієвим засобом регулюючого впливу держави на діяльність закладів освіти з метою дотримання якості освітніх послуг. Але ліцензування не є єдиним засобом регулюючого впливу на якість надання освітніх послуг. Побудова дієвої зовнішньої системи якості освіти, до якої поряд з ліцензуванням відноситься акредитація освітніх програм та інституційна акредитація закладів вищої освіти, стандартизація вищої освіти та освітньої діяльності, дозволить вивести вищу освіту України на рівень, що відповідає Стандартам і рекомендаціям щодо забезпечення якості в Європейському просторі вищої освіти (ESG).

1. Соколова І. В. Управління вищою освітою у зарубіжник країнах. Неперервна професійна освіта: теорія і практика. 2014. № 3-4. С. 98-105. 2. Олейник 0. Правовые основы лицензирования хозяйственной деятельности. Закон. 1994. № 6. С. 15-18. 3. Господарський кодекс України від 16 січня 2003 року № 436-IV. Відомості Верховної Ради України (ВВР). 2003. № 18, № 19-20, № 21-22. Ст. 144. 4. Вєльчева Н. І. Науково-теоретичні основи державного регулювання вищої освіти. Державне будівництво. 2009. № 2. URL: http://nbuv.gov.ua/UJRN/DeBu_2009_2_13. (дата звернення: 15.03.2019). 5. Кобець А. С. Роль держави у функціонуванні ринку освітніх послуг. Державне управління: удосконалення та розвиток. 2011. № 8. URL: http://www.dy.nayka.com.ua/?op=1\&z=308. (дата звернення: 15.03.2019). 6. Шпаков В. В. Механізми державного регулювання господарської діяльності: постановка проблеми. Економічна теорія та право. 2015. № 3 (22). С. 240-251. 7. Михайлушкин П. В., Баранников А. Методы и средства государственного регулирования экономики России: опыт зарубежных стран. Молодой учёный. 2012. № 9 (44). С. 135-140. 8. Кудрейко О. М. Інституційний механізм регулювання модернізації ринку освітніх послуг. Державне управління : наукові праці. Т. 242. № 230. С. 80-85. 9. Карчевський К. А. Ліцензування господарської діяльності: правова природа, джерела правового регулювання,поняття та ознаки. Вісник Харківського національного університету внутрішніх справ. 2009. Вип. 44. С. 180-188. 10. Шестак Л. В. Ліцензування як адміністративно-правовий інститут: дис. ... канд. юрид. наук: спец. 12.00.07 / Національна академія державної податкової служби України. Ірпінь. 2005. 183 с. 11. Шпомер А. Поняття, ознаки та функції ліцензування певних видів господарської діяльності. Господарське право. 2004. № 12. С. 77-80. 12. Авер'янова Є. Поняття ліцензування господарської діяльності. 
Підприємництво, господарство і право. 2017. № 11 (261). С. 59-63. 13. Пастух І. Д. Організаційно-правові засади ліцензування господарської діяльності в Україні : автореф. дис. ... канд. юрид. наук : 12.00.07. К., 2005. 19 с. 14. Про ліцензування видів господарської діяльності : Закон України від 02.03.2015 № 222-VIII. Відомості Верховної Ради (ВВР). 2015. № 23. Ст. 158. 15. Про вищу освіту : Закон України від 01.07.2014 № 1556-VII. Відомості Верховної Ради (ВВР). 2014. № 37-38. Ст. 2004. 16. Про освіту : Закон України від 05.09.2017 № 2145-VIII. Голос України. 2017. 27 верес. (№ 178-179). 17. Червякова Т. А. Место лицензирования в механизме правового регулирования. Весн. Брэсц. унта. Сер. Гісторыя. Эканоміка. Права. 2010. № 2. С. 157-163. URL: https://law.bsu.by/pub/31/Chervyakova_6.pdf. (дата звернення: 15.03.2019). 18. Шпомер А. Ліцензування господарської діяльності (господарсько-правовий аспект): автореф. дис. ... канд. юрид. наук : 12.00.04. Київ. 2006. 22 с. 19. Моніторинг інтеграції української системи вищої освіти в Європейський простір вищої освіти та наукового дослідження: моніторинг, дослідж. : аналіт. звіт / Міжнарод. благод. Фонд «Міжнарод. Фонд дослідж. освіт. політики»; під ред. Т. В. Фінікова, О. І. Шарова. К.: Таксон, 2014. 144 C. URL: http://kvit.ukma.edu.ua/wpcontent/uploads/2015/01/Аналітичний-звіт.pdf. (дата звернення: 15.03.2019).

\section{REFERENCES:}

1. Sokolova I. V. Upravlinnia vyshchoiu osvitoiu u zarubizhnyk krainakh. Neperervna profesiina osvita: teoriia i praktyka. 2014. № 3-4. S. 98-105. 2. Oleinik 0. Pravovye osnovy litsenzirovaniia khoziaistvennoi deiatelnosti. Zakon. 1994. № 6. S. 15-18. 3. Hospodarskyi kodeks Ukrainy vid 16 sichnia 2003 ro-ku № 436-IV. Vidomosti Verkhovnoi Rady Ukrainy (VVR). 2003. № 18, № 19-20, № 21-22. St. 144. 4. Vielcheva N. I. Naukovo-teoretychni osnovy derzhavnoho rehuliuvannia vyshchoi osvity. Derzhavne budivnytstvo. 2009. № 2. URL: http://nbuv.gov.ua/UJRN/DeBu_2009_2_13. (data zvernennia: 15.03.2019). 5. Kobets A. S. Rol derzhavy u funktsionuvanni rynku osvitnikh posluh. Derzhav-ne upravlinnia: udoskonalennia ta rozvytok. 2011. № 8. URL: http://www.dy.nayka.com.ua/?op=1\&z=308. (data zvernennia: 15.03.2019). 6. Shpakov V. V. Mekhanizmy derzhavnoho rehuliuvannia hospodarskoi diialnosti: postanovka problemy. Ekonomichna teoriia ta pravo. 2015. № 3 (22). S. 240-251. 7. Mikhailushkin P. V., Barannikov A. Metody i sredstva hosudarstvennoho rehulirovaniia ekonomiki Rossii: opyt zarubezhnykh stran. Molodoi uchenyi. 2012. № 9 (44). S. 135-140. 8. Kudreiko 0. M. Instytutsiinyi mekhanizm rehuliuvannia modernizatsii rynku osvitnikh posluh. Derzhavne upravlinnia : naukovi pratsi. T. 242. № 230. S. 80-85. 9. Karchevskyi K. A. Litsenzuvannia hospodarskoi diialnosti: pravova pryroda, dzherela pravovoho rehuliuvannia,poniattia ta oznaky. Visnyk Kharkivskoho natsionalnoho universytetu vnutrishnikh sprav. 2009. Vyp. 44. S. 180-188. 10. Shestak L. V. Litsenzuvannia yak administratyvno-pravovyi instytut: dys. ... kand. yuryd. nauk: spets. 12.00.07 / Natsionalna akademiia derzhavnoi podatkovoi sluzhby 
Ukrainy. Irpin. 2005. 183 s. 11. Shpomer A. Poniattia, oznaky ta funktsii litsenzuvannia pevnykh vydiv hospodarskoi diialnosti. Hospodarske pravo. 2004. № 12. S. 77-80. 12. Averianova Ye. Poniattia litsenzuvannia hospodarskoi diialnosti. Pidpryiemnytstvo, hospodarstvo i pravo. 2017. № 11 (261). S. 59-63. 13. Pastukh I. D. Orhanizatsiino-pravovi zasady litsenzuvannia hospodarskoi diialnosti v Ukraini : avtoref. dys. ... kand. yuryd. nauk : 12.00.07. K., 2005. 19 s. 14. Pro litsenzuvannia vydiv hospodarskoi diialnosti : Zakon Ukrainy vid 02.03.2015 № 222-VIII. Vidomosti Verkhovnoi Rady (VVR). 2015. № 23. St. 158. 15. Pro vyshchu osvitu : Zakon Ukrainy vid 01.07.2014 № 1556-VII. Vidomosti Verkhovnoi Rady (VVR). 2014. № 37-38. St. 2004. 16. Pro osvitu : Zakon Ukrainy vid 05.09.2017 № 2145-VIII. Holos Ukrainy. 2017. 27 veres. (№ 178-179). 17. Cherviakova T. A. Mesto lytsenzyrovanyia v mekhanyzme pravovoho rehulyrovanyia. Vesn. Brests. unta. Ser. Historyia. Ekanomika. Prava. 2010. № 2. S. 157-163. URL: https://law.bsu.by/pub/31/Chervyakova_6.pdf. (data zvernennia: 15.03.2019). 18. Shpomer A. Litsenzuvannia hospodarskoi diialnosti (hospodarsko-pravovyi aspekt): avtoref. dys. ... kand. yuryd. nauk : 12.00.04. Kyiv. 2006. 22 s. 19. Monitorynh intehratsii ukrainskoi systemy vyshchoi osvity $v$ Yevropeiskyi prostir vyshchoi osvity ta naukovoho doslidzhennia: monitorynh, doslidzh.: analit. zvit / Mizhnarod. blahod. Fond «Mizhnarod. Fond doslidzh. osvit. polityky»; pid red. T. V. Finikova, O. I. Sharova. K. : Takson, 2014. 144 S. URL: http://kvit.ukma.edu.ua/wp-content/uploads/2015/01/Analitychnyi-zvit.pdf. (data zvernennia: 15.03.2019).

Klimova A. V., Post-graduate Student, The Head of License and Accreditation Department (National University of Water and Environmental Engineering, Rivne)

\section{FUNCTIONS OF LICENSING AS A TOOL OF STATE REGULATION IN THE FIELD OF HIGHER EDUCATION OF UKRAINE}

The article is devoted to the consideration of the essence of the concept of "licensing" that is one of the regulating means of the state to influence the activity of managerial subjects regarding the beginning, proceeding of separately defined activities and further control over its implementation in order to ensure the protection of rights and legitimate interests of citizens, the state and society. The author highlighted the role of the state as a guarantor of ensuring rights and meeting the educational needs, ensuring the compliance of educational activities for the needs of society under the conditions of globalization and the internationalization of higher education, 
strengthening of competition and development of the autonomy of higher education institutions.

It is thus well-proven that government control is the prevailing form of influence on development of higher education in Ukraine, as the state, coming forward as one of subjects of macroeconomics, the main function of that is organization of production of public benefits, provides adjusting of economy, determines terms and rules of conduct of economic activity, sets certain requirements and limitations of activity of subjects of menage, including their responsibility for offence in the field of a menage. While licensing is one of instruments of regulative influence of the state on establishments of higher education and refers to the administrative methods, when a necessary result is arrived at by means of direct influence of central public authority in the sphere of education on establishments of education. The role of educational activity licensing as a element of the system of external quality assurance in higher education are researched. By an author determination of function of licensing: regulatory, legitimation, supervisory, fiscal, permissive, informative, registration, statistical, guard, and disclosed content of every function.

Keywords: higher education, state regulation of educational services provision, external quality assurance in higher education, licensing of educational activities.

Климова А. В., аспирант, заведующая отделом лицензирования и аккредитации (Национальный университет водного хозяйства и природопользования, г. Ровно)

\section{ФУНКЦИИ ЛИЦЕНЗИРОВАНИЯ КАК ИНСТРУМЕНТА} ГОСУДАРСТВЕННОГО РЕГУЛИРОВАНИЯ В СФЕРЕ ВЫСШЕГО ОБРАЗОВАНИЯ УКРАИНЫ

Статья посвящена рассмотрению сущности понятия «лицензирование», что является одним из средств регулирующего воздействия со стороны государства на деятельность субъектов хозяйствования относительно начала, производства отдельных видов деятельности и последующего контроль ее осуществления в целях обеспечения защиты прав, законных интересов граждан, государства и общества.

Автором представлена роль государства как гаранта обеспечения прав и удовлетворения потребностей в сфере образования, обеспечения соответствия образовательной деятельности запросам 
общества в условиях глобализации и интернационализации высшего образования, усилении конкуренции и развития автономии высших учебных заведений. При этом доказано, что государственное регулирование является преобладающей формой влияния на развитие высшего образования в Украине, поскольку государство, выступая одним из субъектов макроэкономики, главной функцией которого является организация производства общественных благ, обеспечивает регулирование экономики, определяет условия и правила ведения хозяйственной деятельности, устанавливает определенные требования и ограничения деятельности субъектов хозяйствования, включая их ответственность за правонарушения в сфере хозяйствования. Тогда как лицензирование является одним из инструментов регулирующего воздействия государства на высшие учебные заведения и относится к административным методам, когда необходимый результат достигается с помощью прямого воздействия центрального органа государственной власти в сфере образования на учебные заведения.

Исследована роль лицензирования образовательной деятельности как элемента системы гарантии качества высшего образования. Автором определены функции лицензирования, в частности: регулятивная, легитимационная, контролирующая, фискальная, разрешительная, информационная, учетная, статистическая, охранная и раскрыто содержание каждой функции.

Ключевые слова: высшее образование, государственное регулирование предоставления образовательных услуг, внешнее обеспечение качества высшего образования, лицензирование предоставления образовательных услуг. 